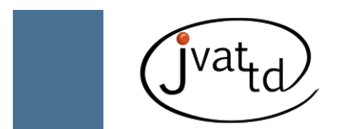

\title{
Prevalence and chemotherapy of babesiosis among Lohi sheep in the Livestock Experiment Station, Qadirabad, Pakistan, and environs
}

\author{
Rashid A (1), Khan JA (2), Khan MS (2), Rasheed K (3), Maqbool A (4), Iqbal J (5)
}

(1) Veterinary Research Institute, Lahore Cantt, Pakistan; (2) Department of Clinical Medicine and Surgery, University of Veterinary and Animal Sciences, Lahore, Pakistan; (3) Institute of Biochemistry and Biotechnology, University of Veterinary and Animal Sciences, Lahore, Pakistan; (4) Department of Parasitology, University of Veterinary and Animal Sciences, Lahore, Pakistan; (5) Livestock Experiment Station, Qadirabad, Sahiwal, Pakistan.

\begin{abstract}
A total of 310 blood smears were collected from sheep of the Livestock Experiment Station, Qadirabad, Sahiwal district, Pakistan, and surrounding areas. The samples were examined microscopically and 30 (9.67\%) were positive for babesiosis. The animals were divided into two groups (A and B) for chemotherapy. Group A sheep were treated with diminazene diaceturate while group B animals received imidocarb dipropionate. Drug efficacy was determined by negative blood smear examination. Diminazene diaceturate effectiveness against babesiosis was $80 \%$ while that of imidocarb dipropionate was $100 \%$. Hematological studies revealed a significant decrease in hemoglobin concentrations and hematocrit values for Babesia-positive animals compared to healthy controls.
\end{abstract}

Key words: babesiosis, sheep, hemoglobin, hematocrit, diminazene, imidocarb, Pakistan.

\section{INTRODUCTION}

The livestock sector plays an important role in the economy of Pakistan. It contributed with about 51.8 percent of the agriculture value and 11.3 percent of the national gross domestic product during 2008 and 2009. The gross value addition of livestock at the current cost factor has increased from Rs. 1052 billion to Rs. 1287 billion, showing a $22.3 \%$ increase (1). Sheep give rise to four major products: meat, wool/hair, milk and skins. In many parts of the world, particularly the temperate regions, meat is the major product and the importance of its production has increased worldwide (2).

Babesiosis is the third most important disease of sheep in Pakistan from an epidemiological point of view (3). The economic losses in small ruminant production are significant in the tropical and subtropical regions of the world (4).

Animals develop fever concurrent with parasitemia within 2 to 4 days; the clinical signs of the disease are severe and include varying degrees of anorexia, listlessness, anemia, moderate jaundice and hemoglobinuria. In intact animals, hyperthermia returned to normal on the fourth day after the peak pyrexia, and parasitemia was eliminated within the course of the disease (5). Chronically infected sheep are usually symptomless, except for parasitemia and unthriftiness (6). In the acute phase, diagnosis of small ruminant piroplasmosis is mainly based on the microscopic examination of Giemsa-stained blood smears and clinical symptoms (7).

During ovine babesiosis, red blood cell count, hematocrit and hemoglobin concentration decrease and neutrophils increase, compared to reference values $(8,9)$. The decrease in the packed cell volume ranges from 30 to $40 \%$ (10). A variety of drugs were used to treat babesiosis in the past, but only diminazene aceturate and imidocarb dipropionate are in common use nowadays (11). Imidocarb diproprionate (IMDP) is of therapeutic and prophylactic value against babesial infections (12-14). The therapeutic efficacy of IMDP against Babesia ovis has been well documented (15-18). 
The present study describes the prevalence and chemotherapy of babesiosis among Lohi sheep in and around the Livestock Experiment Station, Qadirabad, Sahiwal, Pakistan, and focuses on the examination of selected hematological parameters.

\section{MATERIALS AND METHODS}

\section{Field Study Area}

The study was done in and around (Chak 62/4R, Chak 63/4R, Chak 75/5R, Chak 76/4R and Chak 77/4R) the Livestock Experiment Station (LES), Qadirabad, in Sahiwal, which is an important livestock production region in Pakistan (Figure 1). Ecologically, this area is classified as a centrally mixed zone. Its climate is extreme, reaching $52^{\circ} \mathrm{C}$ in the summer and $-5^{\circ} \mathrm{C}$ in the winter. There are also agricultural lands in the area.

\section{Sample Size}

Due to the lack of information about the prevalence of ovine babesiosis in these areas, 310 blood smears were tested. From each flock, five to seven animals were randomly sampled (19).

\section{Blood Smear Examination}

Thin blood smears were prepared immediately after the collection of blood samples and marked in the field. After returning to the laboratory, they were fixed in methanol for five minutes and stained in Giemsa stain diluted at $10 \%$ with buffer solution for 30 minutes; then, they were examined
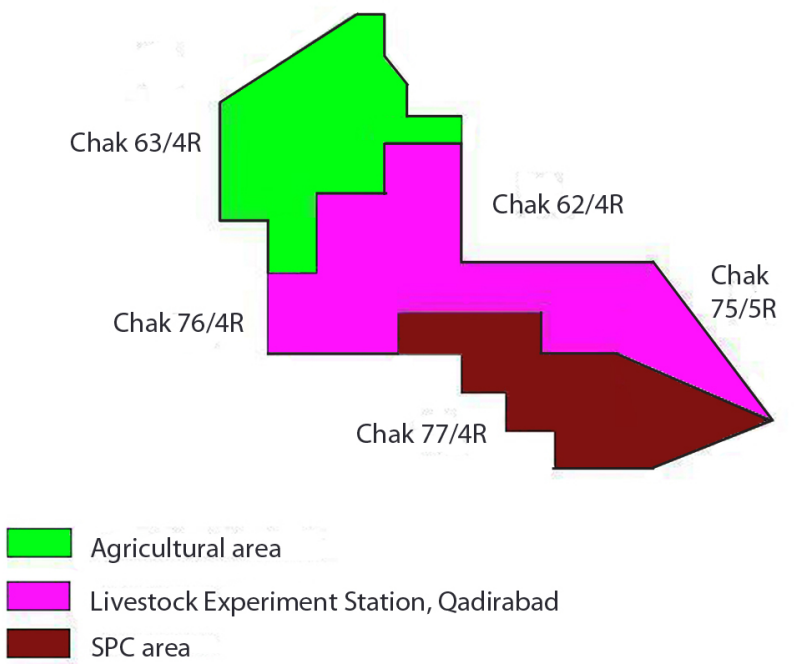

Figure 1. Map of the Livestock Experiment Station (LES), Qadirabad, showing the locations in the current study. with an oil immersion lens at a total magnification of 1000x for the presence of Babesia piroplasms. The smears were recorded as negative for Babesia if no parasites were found in the oil-immersion field.

\section{Drugs}

Diminazene diaceturate and imidocarb dipropionate were purchased commercially. Doses were calculated on the basis of the active principle ingredient of $35 \% \mathrm{w} / \mathrm{v}$ diminazene diaceturate in Diminazene (Star Lab. Ltd., Pakistan) and 12\% w/v imidocarb dipropionate in Imizol $^{\oplus}$ (ICI Pakistan Ltd).

\section{Treatment Schedule}

Thirty sheep positive for babesiosis were divided into three equal groups, each consisting of ten animals. The animals of group A were injected with Diminazene ${ }^{\circledast}$ at a dose rate of $3.5 \mathrm{mg} / \mathrm{kg}$ body weight intramuscularly. In group B, animals were injected with Imizol $^{\circledR}$ intramuscularly at a dose rate of $2 \mathrm{mg} / \mathrm{kg}$ body weight. The animals of group C served as Babesia-infected control.

\section{Hematological Examination}

A volume of $10 \mathrm{~mL}$ blood was collected from the jugular vein of each infected and healthy sheep into labeled tubes containing anti-coagulant. Hematological examination of blood samples from all sheep groups was carried out at day zero (pre-medication) and then at days 3, 7 and 10 post-medication. The effect of babesiosis on hemoglobin and hematocrit was determined by adopting the procedure described by Coles (20).

\section{Statistical Analysis}

The data resulting from the present study were analyzed by Student's t-test. Associations were statistically significant when a $P$-value of less than 0.05 was obtained (21).

\section{RESULTS AND DISCUSSION}

\section{Prevalence}

During the study, a total of 310 Lohi sheep, including 250 adults and 60 lambs, were examined. The sheep were of different ages and both sexes. The overall prevalence of ovine babesiosis in and around the LES, Qadirabad, was 9.67\% (Figure $2)$. Month-wise prevalence showed that three (3.6\%), nine (8.18\%) and 18 (15.38\%) sheep were infected with Babesia in April, May and June, 
respectively. These results are in close agreement with those of Ferrer et al. (22), Yeruham et al. (23) and Aktas et al. (7), who reported 6.1\%, 5.56\% and $8.25 \%$ Babesia ovis infection, respectively. In the present study, the animals were apparently healthy but Babesia organisms were present in their circulation, corroborating the study of Tsomaya (24), who reported Babesia ovis infection in sheep for more than two years after recovery. However, the results of the present study are not in agreement with those of Mazyad and Khalaf (25), who reported very low prevalence, i.e. only $2.73 \%$ Babesia ovis among 475 sheep, which may be due to low existence of vector parasites that spread the disease. In addition, the results of the present study do not correlate to those of Papadopoulos et al. (26), Karatepe et al. (27) and Hosein et al. (28), who reported 52.1\%, 23.63\% and $50.92 \%$ ovine babesiosis, respectively. This difference may be attributed to the application of highly sensitive tests like indirect fluorescent antibody technique for diagnostic purpose.

\section{Chemotherapy}

Diminazene ${ }^{\oplus}$, administered to group A sheep at the dose rate of $3.5 \mathrm{mg} / \mathrm{kg}$ body weight, showed $80 \%$ efficacy at day 10 post-medication (Figure 3 ). These results agree with the study of Baby et al. (29), who treated concurrent babesiosis and anaplasmosis in goat with diminazene. Similar

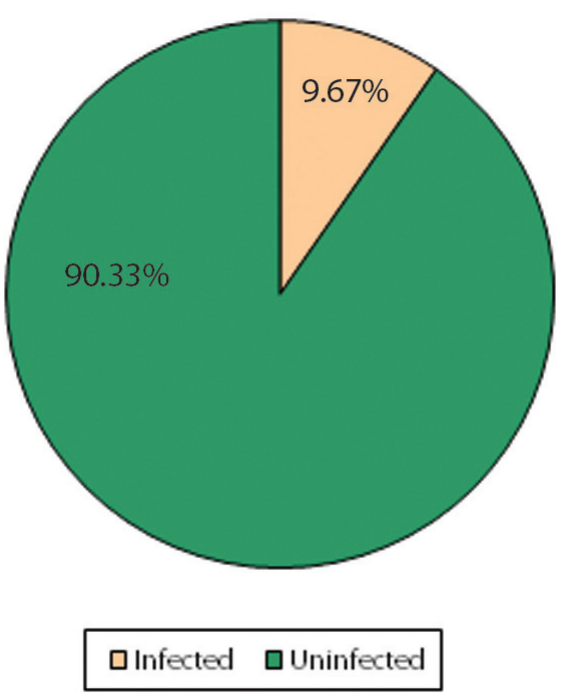

Figure 2. Prevalence of babesiosis among Lohi sheep in and around the Livestock Experiment Station (LES), Qadirabad, Sahiwal (Pakistan). results were also found by Simitch et al. (30), Cordoves and Palano (31), Aliu and Odegaard (32), Mohamed and Yagoub (33) and Manget (34), who obtained a satisfactory effect of diminazene against babesiosis. On the other hand, the present results do not agree with those of Banerjee et al. (35) and Rao et al. (36), who recorded $100 \%$ recovery by diminazene. This may be due to the use of a high dose of diminazene against ovine babesiosis.

Imizol $^{\circledR}$, administered to group B animals at the dose rate of $2 \mathrm{mg} / \mathrm{kg}$ body weight, showed $60 \%$ efficacy at day 3, 90\% at day 7 and $100 \%$ at day 10 post-medication (Figure 3 ). These results are in agreement with those of Ramin (37) and McHardy et al. (18), who recorded $97.28 \%$ and $100 \%$ imidocarb efficacy, respectively, while treating sheep with babesiosis.

\section{Hematology}

For group A, at day zero, mean hemoglobin concentrations and hematocrit values were 7.12 $\pm 0.37 \mathrm{~g} / \mathrm{dL}$ blood and $20.3 \pm 0.78 \%$, respectively. After treatment with diminazene, at days 3, 7 and 10 post-medication, mean hemoglobin concentrations were $7.66 \pm 0.68,8.38 \pm 0.74$ and $8.88 \pm 0.76 \mathrm{~g} / \mathrm{dL}$ blood, respectively, while mean hematocrit values were $23.0 \pm 0.63,25.5 \pm 1.1$ and $27.9 \pm 1.5 \%$, respectively.

For group B, at day zero, mean values of hemoglobin and hematocrit were $7.0 \pm 0.45 \mathrm{~g} / \mathrm{dL}$ blood and $19.8 \pm 0.97 \%$, respectively (Figures 4 and 5). After treatment with imidocarb dipropionate, there was a marked improvement in the health of animals. At days 3, 7 and 10 post-medication,

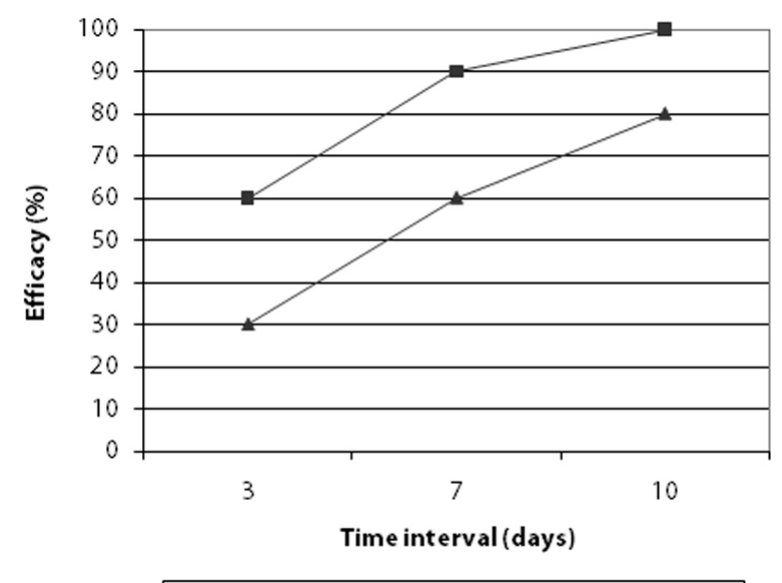

- Diminazene diaceturate - - Imidocarb dipropionate

Figure 3. Comparative efficacy (\%) of drugs at days 3,7 and 10 post-medication for groups $A$ and $B$. 
mean hemoglobin concentrations were $8.48 \pm$ $0.57,9.64 \pm 0.89$ and $11.1 \pm 0.94 \mathrm{~g} / \mathrm{dL}$, respectively, while mean hematocrit values were $25.2 \pm 1.32$, $28.6 \pm 1.0$ and $32.8 \pm 1.1 \%$, respectively.

For the infected control group, hemoglobin and hematocrit values were much more decreased at days 3, 7 and 10 compared to day zero, while group D (healthy control) showed normal values at days zero, 3, 7 and 10 (Figures 4 and 5). The mean values of hemoglobin and hematocrit for all groups were statistically significant $(P<$ $0.05)$. The results of present study correlated to those of Banerjee et al. (35), who reported $6.4 \mathrm{~g} /$ $\mathrm{dL}$ hemoglobin for naturally infected goat with Babesia motasi. The present results also agree with those of Voyvoda et al. (38), who reported hemoglobin and hematocrit values of $7.00 \pm 0.3$ $\mathrm{g} / \mathrm{dL}$ and $19.07 \pm 0.78 \%$, respectively, for naturally infected white karaman sheep with Babesia ovis. In addition, the present findings are similar to those of Baby et al. (29), Gautan and Chaudhary

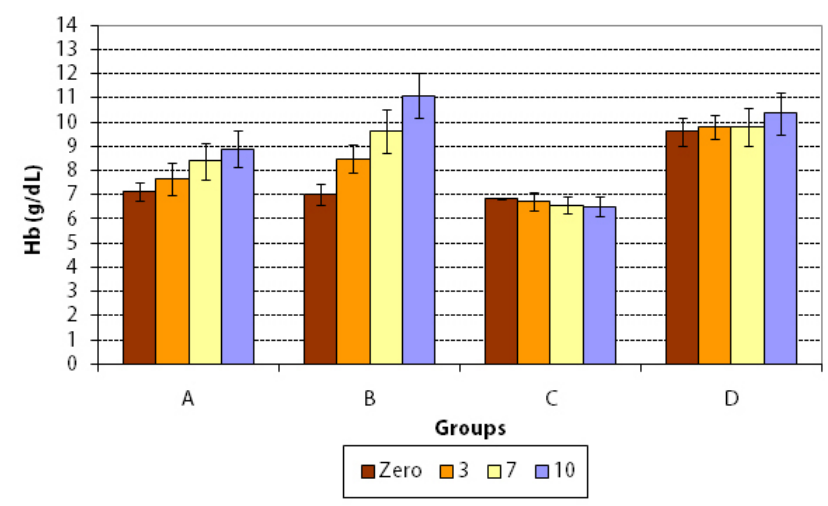

Figure 4. Hemoglobin concentrations for Lohi sheep of different groups at days $0,3,7$ and 10 postmedication.

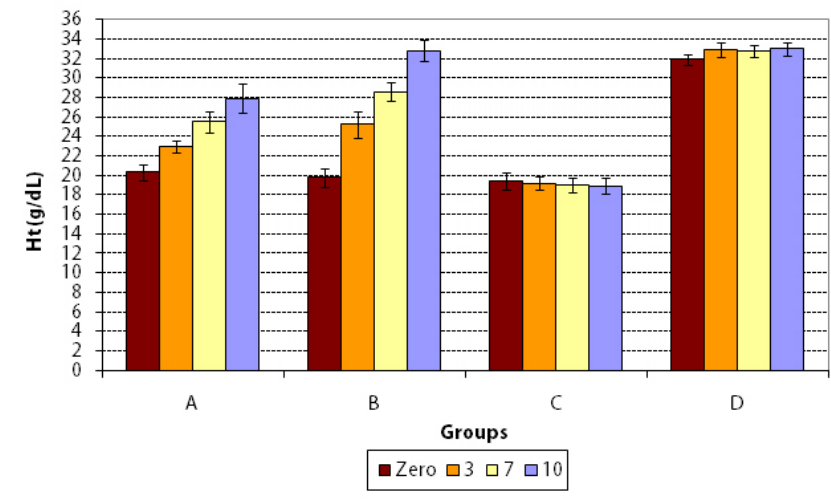

Figure 5. Hematocrit values for Lohi sheep of different groups at days $0,3,7$ and 10 post-medication.
(39), Reid et al. (40) and Yeruham et al. $(10,41)$, who reported a decrease in hemoglobin and hematocrit values during babesiosis. Red blood cell counts reduced due to severe anemia, as well as due to destruction by Babesia.

For group D, hematocrit value was normal (Figure 5). This study is in agreement with that of Bell-Sakyi et al. (42), who reported normal mean packed cell volume for sheep without hemoparasite infection.

In conclusion, the results obtained in this study clarifies that Babesia is an important prevalent pathogen among sheep in and around the LES, Qadirabad. Hematological examination revealed a significant decrease in hemoglobin and hematocrit values for sheep infected with babesiosis. Moreover, imidocarb dipropionate showed better results whereas diminazene diaceturate was the second in efficacy against Babesiosis.

\section{COPYRIGHT}

(C) CEVAP 2010

\section{SUBMISSION STATUS}

Received: February 25, 2010.

Accepted: June 8, 2010.

Abstract published online: June 21, 2010.

Full paper published online: November 30, 2010.

\section{CONFLICTS OF INTEREST}

There is no conflict.

\section{CORRESPONDENCE TO}

ASIF RASHID, Veterinary Research Institute, Ghazi Road, Lahore Cantt 54810, Pakistan. Phone: +92 42 9220136. Email: dr_asif_rasheed@ hotmail.com.

\section{REFERENCES}

1. Mustafa K. Pakistan Economic Survey 2008-09 [Internet]. Islamabad: Ministry of Finance, Islamabad, Government of Pakistan; 2008. Available from: http://www.thenews.com.pk/top_story_detail. asp? Id $=22686$.

2. Morris ST. Economics of sheep production. Small Rum Res. 2009;86(1):59-62.

3. Pakistan Agricultural Research Council (PARC), College of Veterinary Sciences, University of Agriculture, Faisalabad. Epidemiology of Major Livestock Diseases in Pakistan. 1994-95. Islamabad/ Faisalabad: PARC; 1994-95.

4. Mehlhorn H, Shein E. The piroplasms: life cycle and sexual stages. Adv Parasitol. 1985;23(1):37-103.

5. Rahbari S, Nabian S, Khaki Z, Alidadi N, Ashrafihelan 
J. Clinical, haematologic and pathologic aspects of experimental ovine babesiosis in Iran. Iran J Vet Res. 2008;9(1):59-64.

6. Kimberling CV, Jensen R, Swift BL. Jenson and Swift's diseases of sheep. 3rd ed. Philadelphia: Lea \& Febiger; 1988. p. 368-9.

7. Aktas M, Altay K, Dumanli N. Determination of prevalence and risk factors for infection with Babesia ovis in small ruminants from Turkey by polymerase chain reaction. Parasitol Res. 2007;100(4):797-802.

8. Peinado VI, Fernandez-Arias A, Viscor G, Palomeque J. Haematology of Spanish ibex (Capra pyrenaica hispanica) restrained by physical or chemical means. Vet Rec. 1993; 132(23):580-3.

9. Peinado VI, Fernandez-Arias A, Zabala, JL, Palomeque J. Effect of captivity on the blood composition of Spanish ibex (Capra pyrenaica hispanica). Vet Rec. 1995;137(23):588-91.

10. Yeruham I, Hadani A, Galker F, Avidar Y, Bogin E. Clinical, clinico-pathological and serological studies of Babesia ovis in experimentally infected sheep. Zentralbl Veterinarmed B. 1998;45(7):385-94.

11. Aiello SE. The Merck Veterinary Manual. 8th ed. Whitehouse Station: Merck and Co. Inc.; 2008. p. 537-9.

12. Zintl A, Mulcahy G, Skerrett HE, Taylor SM, Gray JS. Babesia divergens, a bovine blood parasite of veterinary and zoonotic importance. Clin Microbiol Rev. 2003;16(4):622-36.

13. Vial HJ, Gorenflot A. Chemotherapy against babesiosis. Vet Parasitol. 2006;138(1-2): 147-60.

14. Joyner LP. The chemotherapy of protozoal infections of veterinary importance. J Protozool. 1981;28(1):17-9.

15. Hashemi-Fesharki R. Studies on imidocarb dihydrochloride in experimental Babesia ovis infection in splenectomized lambs. Br Vet J. 1977;133(6):609-14.

16. Michael SA, El Refaii AH. The effect of imidocarb dipropionate on Babesia ovis infection in sheep. Trop Anim Health Prod. 1982;14(1):1-2.

17. Hashemi-Fesharki R. Ovine and caprine babesiosis in Iran: treatment with imidocarb. Vet Rec. 1991;129(17):383-4.

18. McHardy N, Woollon RM, Clampitt RB, James JA, Crawley RJ. Efficacy, toxicity and metabolism of imidocarb dipropionate in the treatment of Babesia ovis infection in sheep. Res Vet Sci. 1986;41(1):14-20.

19. Thrusfield M. Veterinary epidemiology. 2nd ed. Oxford: Blackwell Science; 1997. 496 p.

20. Coles EH. Veterinary clinical pathology. 4th ed. Philadelphia: W. B. Saunder's Company; 1986. p. 15-7.

21. Moore DS, McCabe GP. Inference for distributions. In: Moore DS, McCabe GP, editors. Introduction to the practice of statistics. New York: WH Freeman and Company; 1989. p. 713-59.

22. Ferrer D, Castella J, Gutierrez JF. Seroprevalence of Babesia ovis in sheep in Catalonia, northeastern Spain. Vet Parasitol. 1998;79(4):275-81.

23. Yeruham I, Hadani A, Galker F, Rosen S, Schlien J. A field study of haemoparasites in two flock of sheep in Israel. Isr J Vet Med. 1992;47(3):107-11.

24. Tsomaya V. Active immunization of sheep against Babesiosis. Veterinariya. 1960;37(3): 31.
25. Mazyad SA, Khalaf SA. Studies on Theileria and Babesia infecting live and slaughtered animals in Al Arish and El Hasanah, North Sinai Governorate, Egypt. J Egypt Soc Parasitol. 2002;32(2):601-10.

26. Papadopoulos B, Perie NM, Uilenberg G. Piroplasms of domestic animals in the Macedonia region of Greece. 1. Serological cross-reactions. Vet Parasitol. 1996;63(1-2):41- 56.

27. Karatepe M, Karatepe B, Cakmak A, Nalbantoglu S. Prevalence of Babesia ovis in sheep and goats in the region of Nigde. Turkiye Parazitoloji Dergisi. 2003;27(1):18-20.

28. Hosein HI, Ahmed SA, Ibrahim FA, Abou-Elnaga TR, Gebely MA, Mahmoud MA. Seroprevalence of Babesia ovis in small ruminants in Siwa Oasis, Egypt. Bs Vet Med J. 2007;17(1):19-24.

29. Baby PG, David PV, Ravindran P, Ravindran R. A subacute case of concurrent babesiosis and anaplasmosis in a she-goat. Ind Vet J. 2001;78(5):424-5.

30. Simitch CP, Nevenic VS, Sibalic S. Le traitment de la piroplamose ovine et la piroplasmose bovine par berenil. Acta Vet Belgrad. 1956;6:3-13.

31. Cordoves CD, Polanco R. Efficacy of Ganasegur (diminazene) in the control of trypanosomiasis and babesiosis. Veterinaria. 1983;5:133-8.

32. Aliu YO, Odegaard S. Pharmacokinetics of diminazene in sheep. J Pharmacokinetic Biopharm. 1985;13(2):173-84.

33. Mohamed AA, Yagoub IA. Outbreaks of babesiosis in domestic livestock in the eastern region of Sudan. Trop Anim Health Prod. 1990;22(2):123-5.

34. Manget IS. Package of practices in veterinary and animal husbandry for livestock and poultry. Ludhiana: Punjab Agriculture University; 1983. 126 p.

35. Banerjee PK, Guha C, Gupta R. A note on incidence of Babesia motasi infection in a goat in West Bengal. Indian Vet J. 1987;64(1):71-3.

36. Rao PB, Surendran NS, Rao PVR. Study on outbreaks of babesiosis in sheep in Andhra Pradesh. Ind Vet J. 1989;66(1):348-51.

37. Ramin AG. The chemotherapeutic effect of 'Imidocarb' against ovine babesiosis in Iran. Ind Vet J. 2000;77(12):1078-80.

38. Voyvoda H, Sekin S, Kaya A, Bildik A. Modifications of serum iron, copper concentration (SI, Cu), total and latent iron-binding capacity (TIBC, LIBC) and transferring saturation (TS) in natural Babesia ovis infection in sheep. Turk J Vet Anim Sci. 1997;21(1):31-7.

39. Gautan OP, Chaudhary RGK. India conference on blood protozoan disease. Hisar; 1972.

40. Reid JF, Armour J, Jennings FW, Urquhart GM. Babesia in sheep-first isolation. Vet Rec. 1976;99(21):419.

41. Yeruham I, Hadani A, Galker F. Some epizootiological and clinical aspects of ovine babesiosis caused by Babesia ovis: a review. Vet Parasitol. 1998;74(2-4):15363.

42. Bell-Sakyi L, Koney EB, Dogbey O, Walker AR. Incidence and prevalence of tick-borne haemoparasites in domestic ruminants in Ghana. Vet Parasitol. 2004;124(1-2):25-42. 